\title{
Enhancing Water Productivity of Rainfed Bt. Cotton (Gossypium hirsutum L.) through Various Agronomic Practices
}

\author{
P. N. More*, M. P. Jagtap, A. S. Jadhav and A. J. Rathod \\ Department of Agronomy, VNMKV Parbhani, India \\ *Corresponding author
}

\section{A B S T R A C T}

K e y w o r d s
Water productivity
Bt. Cotton,
Agronomic
practices

Keywords

Water productivity Bt. Cotton, Agronomic practices

10 December 2020
Experiment on Enhancing Water Productivity of Rainfed Bt. Cotton (Gossypium hirsutum L.) Through Various Agronomic Practices was conducted at Agronomy Research farm, Department of Agronomy, VNMKV, Parbhani during Kharif, 2018, to investigate the effect of agronomic practices on water productivity of Bt. Cotton. The experiment was laid out in randomized block design, replicated thrice with seven treatments. Treatments were $\mathrm{T}_{1}$ - Opening furrow (Every row) $30 \mathrm{DAS}, \mathrm{T}_{2}$ - Opening furrow (Alternate row) $30 \mathrm{DAS}$, $\mathrm{T}_{3}$ - Straw mulching $30 \mathrm{DAS}, \mathrm{T}_{4}$ - Application of herbicide (Pyrithiobac sodium PE + POE), $\mathrm{T}_{5}$ - Application of Superabsorbent @ $5 \mathrm{~kg} \mathrm{ha}^{-1}, \mathrm{~T}_{6}$ - Intercropping [Cotton + soybean (1:2)], $\mathrm{T}_{7}-$ Recommended practices (Control). The result of this study showed that Maximum Seed cotton yield $\left(2116.41 \mathrm{Kg}^{-1}\right)$, Water productivity $\left(0.54 \mathrm{~kg} \mathrm{~m}^{3}\right)$, Gross water productivity $\left(29.11 \mathbf{F}^{3}\right)$ and Net water productivity $\left(15.26 ₹ \mathrm{~m}^{3}\right)$ were recorded significantly in treatment $\mathrm{T}_{1}$ - Opening furrow in (every row) $30 \mathrm{DAS}$.

\section{Introduction}

Water is the most crucial input for agricultural production. Globally, agriculture accounts for more than $80 \%$ of all freshwater used by humans, most of that is for crop production (Morison et al., 2008). Currently most of the water used to grow crops is derived from rainfed soil moisture, with non-irrigated agriculture accounting for about $60 \%$ of production in developing countries. Though irrigation provides only $10 \%$ of agricultural water use and covers just around $20 \%$ of the cropland, it can vastly increase crop yields, improve food security and contribute about $40 \%$ of total food production since productivity of irrigated land is almost three times higher than that of rainfed land. The Food and Agriculture Organization has predicted a net expansion of irrigated land of about 45 million hectares in 93 developing countries (for a total of 242 million hectares in 2030) and projected that water withdrawals by the agriculture sector will increase by about $14 \%$ during 2000 - 2030 to meet food demand (FAO, 2006).

Among the various environmental stresses adversely affect the growth and development of plants, most damaging one is water deficit (drought) stress (Sinclair, 2005). Drought attacks crop plants in many regions of the 
world and responsible for yield losses depending upon the duration and severity of the stress. Growing more crops per drop of water use is the key to mitigating the water crisis, and this is a big challenge to many countries. Vagaries of monsoon and declining water table due to over exploitation have resulted in shortage of fresh water supplies for agricultural use, which calls for an efficient use of this resource. Strategies for efficient management of water for agricultural use involves conservation of water, integrated water use, optimal allocation of water and enhancing water productivity of crops (Singh, 2010).

Water productivity or Water use efficiency by crops can be enhanced by (i) selection of crops and cropping systems based on available water supplies and (ii) increasing seasonal evapo-transpiration (ET) (prihar 2000). Seasonal evapo-transpiration is a measure of consumptive water use by the crops. Increasing the transpiration (T) component of evapo-transpiration (ET) results in higher utilization of water by the crops to increase the productivity. The rate of development of crop canopy and root system and the extent of soil wetting determine the relative fraction of ET lost as evaporation (E) or Transpiration (T). Seasonal evapotranspiration can be increased by selection of irrigation method, irrigation scheduling, tillage, mulching and fertilization (Saini and Chandra, 2010).

WUE is the yield of harvested crop product achieved from the water available through rainfall, irrigation and soil water storage. Improving WUE in agriculture will require an increase in crop water productivity (an increase in marketable crop yield per unit of water removed by plant) and a reduction in water losses from the crop root zone. The amount of water required for food production depends on the quantity of agricultural commodities produced. For comprehensive improvement of WUE in agriculture, it is necessary to raise the following ratios to their maximum: soil-stored water content/ water received through rainfall and irrigation, water consumption/ soil storage of water, transpiration/ water consumption, biomass yield/ transpiration, and economic benefit/ biomass yield. Up gradation of all these component parameters is the key issue for enhancing WUE (Singh, 2010).

Enhancing water productivity of crop is a paramount objective, particularly in arid and semi-arid areas with erratic rainfall patterns. Under rainfed conditions, soil water may be lost from the soil surface through evaporation or through plant uptake and subsequently lost via stomata on plant leaves (Transpiration). It can also be lost through runoff and deep percolation through soil. Improving WUE in arid and semi-arid areas depends on effective conservation of moisture and efficient conservation of moisture and efficient use limited water (Singh, 2010).

Agronomic practices can improve the water use efficiency/water productivity by applying mulching, selecting rapid growth, early sowing weed control improve runoff and infiltration rate intercropping. (Gregory, 1998).

\section{Materials and Methods}

A field experiment on Enhancing Water Productivity of rainfed Bt. Cotton (Gossypium hirsutum L.) Through Various Agronomic Practices was conducted at Agronomy Research farm, Department of Agronomy, VNMKV, Parbhani during Kharif, 2018, to evaluate the effect of agronomic practices on water productivity of rainfed Bt. Cotton. The net plot size was $6.0 \mathrm{~m} \times 5.7 \mathrm{~m}$ and gross plot size was $9.0 \mathrm{~m} \times 6.0 \mathrm{~m}$. The hirsutum Bt. hybrid (Ajeet-155) was dibbled at spacing of 
$150 \times 30 \mathrm{~cm}$. The experiment was laid out in randomized block design, replicated thrice with seven treatments. The allocated treatments were $\mathrm{T}_{1}$ - Opening furrow (Every row) $30 \mathrm{DAS}, \mathrm{T}_{2}$ - Opening furrow (Alternate row) $30 \mathrm{DAS}, \mathrm{T}_{3}$ - Straw Mulching $30 \mathrm{DAS}$, $\mathrm{T}_{4}$ - Application of herbicide (Pyrithiobac sodium PE + POE), $\mathrm{T}_{5}$ - Application of Superabsorbent @ $5 \mathrm{~kg} \quad \mathrm{ha}^{-1}, \mathrm{~T}_{6}$ Intercropping (Cotton + soybean (1:2)), $\mathrm{T}_{7}$ Recommended practices (Control). Experimental field was leveled and soil was well drained, clayey in texture, medium in nitrogen $\left(258 \mathrm{Kg} \mathrm{ha}^{-1}\right)$, low in available phosphorus (11 Kg ha ${ }^{-1}$ ), rich in available potassium (432 $\mathrm{Kg} \mathrm{ha}{ }^{-1}$ ), $0.51 \%$ Organic carbon and (PH 7.7) slightly alkaline in reaction.

The effective rainfall was $562 \mathrm{~mm}$ against total rainfall received $727 \mathrm{~mm}$. All the agronomic package of practices including fertilizer dose application (120:60:60 NPK $\mathrm{Kg} / \mathrm{ha}$ ) and plant protection measures were followed as per the recommendations. The statistical analysis was done as per procedure suggested by Panse and Sukhatme (1967). The observation regarding soil moisture at 15 , $30,45 \mathrm{~cm}$ depth at different growth stages were recorded in 2018-19. Water productivity, was worked out by dividing the grain yield by total water used (Palanisami and Ramesh, 2009). It was calculated by the formula given below.

\section{Water productivity $\left(\mathrm{kg} \mathrm{m}^{3}\right)$}

$$
\begin{gathered}
\text { Water productivity } \\
\left(\mathrm{Kg} \mathrm{m}^{3}\right)
\end{gathered}=\frac{\text { Seed cotton yield }\left(\mathrm{Kg} \mathrm{ha}^{-1}\right)}{\text { Total water used }\left(\mathrm{m}^{3}\right)}
$$

\section{Gross Water productivity $\left(\boldsymbol{F}^{\mathbf{3}}\right.$ )}

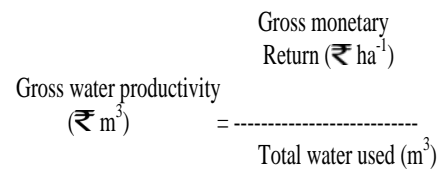

\section{Net Water productivity $\left(₹ \mathbf{m}^{3}\right)$}

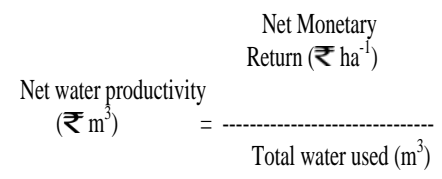

\section{Results and Discussion}

The effect of different agronomic practices on water productivity was observed to be significant.

\section{Seed cotton yield $\left(\mathrm{kg} \mathrm{ha}^{-1}\right)$}

The data on mean seed cotton yield $\left(\mathrm{Kg} \mathrm{ha}^{-1}\right)$ as influenced by different treatments is present in table 1 . The mean seed cotton yield was $\left(1674.23 \mathrm{Kg} \mathrm{ha}^{-1}\right)$. Opening furrow every row 30 DAS $\left(\mathrm{T}_{1}\right)$ treatment recorded highest seed cotton yield (2116.41 $\left.\mathrm{Kg} \mathrm{ha}^{-1}\right)$ which was at par with $\left(\mathrm{T}_{2}\right)$ opening furrow in alternate row, $\left(\mathrm{T}_{3}\right)$ straw mulching, $\left(\mathrm{T}_{6}\right)$ and significantly superior over rest. Control i.e. $\left(\mathrm{T}_{7}\right)$ recorded the lowest seed cotton yield (1311.84 Kg ha ${ }^{-1}$ ). This result supported with finding of Paslawar and Deotalu (2015), Patode et al., (2017), Ganpathi et al., (2018).

\section{Water productivity $\left(\mathrm{kg} \mathrm{m}^{3}\right)$}

Water productivity is an important trait used to estimate the drought tolerance of crops. The different agronomic treatments showed significant effect on water productivity of Rainfed Bt. Cotton. The Data on mean water productivity of Bt. cotton was influenced by different treatments is presented in table 1 . Among the different agronomic treatments $\left(\mathrm{T}_{1}\right)$ opening furrow every row 30 DAS recorded highest water productivity i.e. $(0.54$

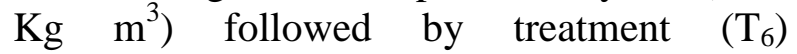
intercropping (Cotton + soybean (1:2) and $\left(\mathrm{T}_{3}\right)$ Straw mulching 30 DAS. Similar trend was observed by Halemani et al., (2004) and Patode et al., (2017). 
Table.1 Water productivity $\left(\mathrm{kg} \mathrm{m}^{3}\right)$, gross water productivity $\left(\boldsymbol{₹}^{3} \mathrm{~m}^{3}\right)$, net water productivity $\left.\left(\boldsymbol{F}^{3}\right)^{3}\right)$ rain water use efficiency $\left(\mathrm{Kg} \mathrm{ha}^{-1} \mathrm{~mm}^{-1}\right)$ and seed cotton yield $\left(\mathrm{Kg} \mathrm{ha}^{-1}\right)$ of rainfed Bt. cotton as influenced by different agronomic treatments

\begin{tabular}{|c|c|c|c|c|c|c|}
\hline Tr. No. & Treatments & $\begin{array}{c}\text { Seed cotton } \\
\text { yield } \\
\left(\mathbf{k g ~ h a}^{-1}\right)\end{array}$ & $\begin{array}{c}\text { Water } \\
\text { Productivity } \\
\left(\mathrm{Kg} \mathrm{m}^{\mathbf{3}}\right)\end{array}$ & $\begin{array}{c}\text { Gross } \\
\text { Water } \\
\text { Productivit } \\
\mathbf{y} \\
\left(\sum^{-} \mathbf{m}^{3}\right)\end{array}$ & $\begin{array}{c}\text { Net } \\
\text { Water } \\
\text { Productivity } \\
\left(\boldsymbol{\Sigma}^{\mathbf{2}} \mathbf{m}^{\mathbf{3}}\right)\end{array}$ & $\begin{array}{c}\text { RWUE } \\
\left(\mathrm{Kg} \mathrm{ha}^{-1} \mathrm{~mm}^{-1}\right)\end{array}$ \\
\hline $\mathbf{T}_{1}$ & $\begin{array}{l}\text { Opening Furrow } \\
\text { (Every row) } 30 \\
\text { DAS }\end{array}$ & 2116.41 & $\begin{array}{c}0.54 \\
(58.82 \%)\end{array}$ & 29.11 & 15.26 & 3.76 \\
\hline $\mathbf{T}_{2}$ & $\begin{array}{l}\text { Opening Furrow } \\
\text { (Alternate row) } 30 \\
\text { DAS }\end{array}$ & 1863.49 & $\begin{array}{c}0.48 \\
(41.17 \%)\end{array}$ & 25.70 & 12.64 & 3.31 \\
\hline $\mathbf{T}_{3}$ & $\begin{array}{l}\text { Straw Mulching } 30 \\
\text { DAS }\end{array}$ & 1945.82 & $\begin{array}{c}0.50 \\
(47.05 \%)\end{array}$ & 26.81 & 12.84 & 3.45 \\
\hline $\mathbf{T}_{4}$ & $\begin{array}{l}\text { Application of } \\
\text { herbicide } \\
\text { (Pyrithioback } \\
\text { sodium PE +POE) }\end{array}$ & 1635.41 & $\begin{array}{c}0.42 \\
(23.52 \%)\end{array}$ & 22.62 & 11.37 & 2.90 \\
\hline $\mathbf{T}_{5}$ & $\begin{array}{l}\text { Application of } \\
\text { Superabsorbent @ } \\
5 \mathrm{Kg} \mathrm{ha}^{-1}\end{array}$ & 1719.87 & $\begin{array}{c}0.44 \\
(29.41 \%)\end{array}$ & 23.76 & 11.26 & 3.05 \\
\hline $\mathbf{T}_{6}$ & $\begin{array}{l}\text { Intercropping } \\
\text { (Cotton + soybean } \\
(1: 2))\end{array}$ & $\begin{array}{c}1126.77 \\
(\mathrm{CEY}=573.22 \\
)\end{array}$ & $\begin{array}{c}0.51 \\
(50 \%)\end{array}$ & 23.30 & 11.36 & 3.02 \\
\hline $\mathbf{T}_{7}$ & $\begin{array}{l}\text { Control } \\
\text { (Recommended } \\
\text { practices) }\end{array}$ & 1311.84 & 0.34 & 18.56 & 6.72 & 2.33 \\
\hline \multicolumn{2}{|c|}{ General mean } & 1674.23 & $0.46(35.71 \%)$ & 24.27 & 11.49 & 2.97 \\
\hline
\end{tabular}

Table.2 Economics rainfed Bt. cotton as influenced by different agronomic treatments

\begin{tabular}{|c|c|c|c|c|}
\hline Tr.No & Treatment & $\begin{array}{c}\text { GMR } \\
\left(\text { ₹ }^{-} \mathbf{h a}^{-1}\right)\end{array}$ & 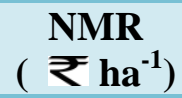 & $\mathbf{B : C}$ \\
\hline $\mathbf{T}_{1}$ & Opening furrow (Every row) 30 DAS & 112067.70 & 58761.01 & 2.10 \\
\hline $\mathbf{T}_{2}$ & Opening furrow (Alternate row) 30 DAS & 98928.66 & 48648.66 & 1.96 \\
\hline $\mathbf{T}_{\mathbf{3}}$ & Straw mulching $30 \mathrm{DAS}$ & 103219.00 & 49447.55 & 1.91 \\
\hline $\mathbf{T}_{4}$ & $\begin{array}{l}\text { Application of herbicide (Pyrithioback sodium } \\
\text { PE + POE) }\end{array}$ & 87105.16 & 43777.47 & 2.01 \\
\hline $\mathbf{T}_{5}$ & Application of Superabsorbent @ $5 \mathrm{Kg} \mathrm{ha}^{-1}$ & 91469.66 & 39506.83 & 1.76 \\
\hline $\mathbf{T}_{6}$ & Intercropping (Cotton + soybean $(1: 2))$ & 89737.53 & 43737.6 & 1.95 \\
\hline $\mathbf{T}_{7}$ & Control (Recommended practices) & 70460.54 & 25894.98 & 1.58 \\
\hline \multicolumn{2}{|l|}{$\mathrm{SE} \pm$} & 5953.47 & 3317.40 & -- \\
\hline \multicolumn{2}{|c|}{ CD at $5 \%$} & 18343.29 & 10221.28 & -- \\
\hline \multicolumn{2}{|c|}{ General mean } & 93418.57 & 44253.22 & 1.89 \\
\hline
\end{tabular}




\section{Gross Water productivity (₹ $\left.\mathrm{m}^{3}\right)$}

The gross water productivity was significantly affected by agronomic treatments. Among the different agronomic treatment, maximum gross water productivity was recorded in treatments $\left(T_{1}\right)$ opening furrow (Every row) 30 DAS followed by treatment $\left(\mathrm{T}_{3}\right)$ Straw mulching 30 DAS and $\left(\mathrm{T}_{2}\right)$ Opening furrow (Alternate row) 30 DAS. Similar result obtained by Tehereema et al., (2010) and vekaria et al., (2020).

\section{Net water productivity $\left(₹ \mathbf{m}^{3}\right)$}

Data in Table 1 presents that the mean net water productivity of $B t$. cotton as influenced by different treatments. Mean net water productivity in $B t$. cotton is recorded as $\left(11.49 ₹ \mathrm{~m}^{3}\right)$. Treatments $\left(\mathrm{T}_{1}\right)$ opening furrow every row 30 DAS recorded highest net water productivity i.e. $\left(15.26 ₹^{3} \mathrm{~m}^{3}\right)$.

Followed by treatment $\left(\mathrm{T}_{2}\right)$ opening furrow alternate row 30 DAS and $\left(\mathrm{T}_{3}\right)$ straw mulching recorded the net water productivity $\left(12.64 \mathrm{~F}^{\mathrm{T}} \mathrm{m}^{3}\right)$ and $\left(12.84 \mathrm{~F}^{3} \mathrm{~m}^{3}\right)$ respectively. Treatment $\left(\mathrm{T}_{7}\right)$ control recorded the lowest water productivity $\left(6.72 \mathrm{~F}^{3}\right)$.similar result were reported by Tehereema et al., (2010) and vekaria et al., (2020).

\section{Rain water use efficiency $\left(\mathrm{Kg} \mathrm{ha}^{-1} \mathrm{~mm}^{-1}\right)$}

Highest rain water use efficiency $\left(3.76 \mathrm{~kg} \mathrm{ha}^{-1}\right.$ $\mathrm{mm}^{-1}$ ) was recorded by opening furrow every row and least was recorded by control $2.33 \mathrm{~kg}$ $\mathrm{ha}^{-1} \mathrm{~mm}^{-1}$.

The increase in rain water use efficiency by various agronomic practices indicates conservation of rain water due to its application. These results are in conformity with Ugale et al., (2000) vekaria et al., (2020).

\section{Economics}

Among the different Agronomic treatments, the treatment Opening furrow (Every row) 30 DAS recorded significantly highest GMR and NMR as compared to the rest of the agronomic treatments. Similar results were reported by Fiske (2004), Hulihali and patil (2005), Gaidhane et al., (2007), Tayade and Meshram (2013), Narayana et al., (2011), santosh et al., (2016) and Patode et al., (2017) (Table 2).

In conclusion the experimental findings revealed that, In rainfed $B t$. Cotton water productivity, Gross water productivity and Net water productivity enhanced due to adaptation of agronomic practices of opening furrow in (every row) 30 DAS and opening furrow alternate row 30 DAS and straw mulching 30 DAS.

\section{References}

Fiske, A.V. 2006. In-situ moisture conservation and integrated nutrient management for improving yield of arboretum cotton (var. AKA-7) M.Sc. Thesis (unpub), DR. PDKV, Akola.

Gaidhane, S.N., Mankar, P.B. Khawale, V.S. and Yepediwar, M.D. 2007. Effect of land configuration and mulches on growth and yield of arborium cotton. $J$. Soils \& Crops. 17(2):403-406.

Ganpathi, S., S. Bharathi, M. Sree Rekha and Jayalalitha, K. 2018 Effect of moisture conservation and nutrition management practices on leaf area, chlorophyll content and seed cotton yield of rainfed Bt cotton. Int. J. Che. Stu. 6(5):539542.

Goureddy B.S., Pujari, B.T. Satyanarayanrao, V.S. and Gadale, A.K. 1995. Influence of plant population, sowing dates \& moisture conservation methods on yield of DCH-12 cotton. J. Maharashtra 
Agri. Univ 20(1): 88-89.

Gregory, P.J. 1988. Plant and management factors affecting the water use efficiency of dryland crops In: Proc. Int. Conf. On Dryland farming, Amarillo, Bushland, pp. 171-175.

Halemani, H.L., Hallikeri, S.S., Antravali, M.B. and Nandagavi, R.A. 2002. Studies on dru sowing and rain water Harvesting in rainfed cotton. Journal of Indian Society and Cotton Improvement. 27:94-99.

Hulihali, V.K. and Patil, V.C. 2005. Effect of in-situ misture conservation practices and organic manure on yield and quality of (G. hirsutum L.) grown on vertisols $P K V$-Res J. 30(2):135-143.

Morison, J.I.L., Baker, N.R., Mullineaux, and Davies, W.J. 2008 Improving water use in crop production. Philosophical Transactions of the Royal Society of London B. Bio. Sci. 363(1491), 639658.

Narayana, E., Aparna, D and Mridula, G. 2011. Response of Bt. Cotton (Gossypium hirsutum L.) for integrated rain water and nutrient management. Journal of Cotton Research and Development. 25 (1):68-70.

Palanisami, K. and Ramesh, T. 2009. Water Productivity at Farm level in Bhavani Basin, Tamilnadu: Estimation, challenges and approaches. Available online http://nrlp.iwmi.org/ PDocs/DReports/phase-01/09.(pdf)12 pages.

Panse, V.G. and P.V. Sukhatme. 1967. Statistical Methods for Agricultural Gaidhane, S.N., P.B. Mankar, V.S. Khawale, M.D. Yepediwar, 2007. Effect of land configuration and mulches on growth \& Yield of arborium cotton. J. Soils \& Crops. 17(2):403-406.Workers, $1^{\text {st }}$ Edn., ICAR, New Delhi.

Parihar, S.S., Gajri, P.R., Benbi, D.K. and
Arora, V.K. 2000. Intensive cropping Efficient use of water, nutrients, and Tillage. Food Products Press. pp68.

Paslawar, A. N., and Deotalu, A. S. 2015 Impact of soil moisture conservation practices and nutrient management under high density planting system of cotton. Int. J. Engi. Sci. Vol. 4 (9) pp34-36.

Patode R.S., M.B. Nagdeve, M.M. Ganvir and Gabhane, V.V. 2017 Evaluation of insitu moisture conservation practices for sustainable production of major crops In Vidarbha Region. Int. J. Curr. Microbiol. App. Sci. 6(10): 261-268.

Saini, S. and Chandra, S. 2010. - Water conservation and utilization in Agriculture production, Satish Serial Publishing House., Azadpur, New Delhi.

Santosh, U.N., Satyanarayan, R., Biradar, S.A., Desai, B.K., Halepyati, A.S. and Koppalkar, B.G. 2016. Response of soil and foliar nutrition on Bt. cotton (Gossypium hirsutum L.) quality, yield parameters and economics under irrigation. Journal of Cotton Research and Development. 30(2): 205-209.

Sinclair, T. R. 2005. Theoretical analysis of soil and plant traits influencing daily plant water flux on drying soils. $J$. of Agronomy. 97: 1148-1152.

Singh, R., Kundu, D. K. Bandyopadhyay, K.K. 2010 Enhancing Agricultural Productivity through Enhanced Water Use Efficiency. J. of Agril. Phy. Vol.10, pp.1-15.ISSN 0973-032X.

Tayade, A. S., And Meshram, M. K. 2013 Impact of dry sowing and in-situ moisture conservation on productivity of rainfed cotton. J. of cotton Res. Dev., 2013, Vol. 27, No. 1, PP. 66-69.

Tehreema Iftikhar, Lall Khan Babar, Sarwat Zahoor and Nasir Ghafoor Khan 2010. Impact of land pattern and hydrological properties of soil on seed cotton yield. 
Pak. J. Bot., 42 (5):3023-3028.

Ugale, N. S., Shinde, S.H. and Jadhav, V.T. 2000. Response of chickpea var. vijay to field layouts \& irrigation depths. $J$. Maharashtra Agri. Univ. 25(1):79-80.
J.T. Sharma, G.R. Vadar, H.R. \& Hirpara, D.S. 2020 In-Situ Moisture Conservation In Rainfed Stressed Regions For Increasing Productivity of Cotton Crop. Int.J.Curr. Microbiol. App.Sci. 9(09):777-781.

\section{How to cite this article:}

More, P. N., M. P. Jagtap, A. S. Jadhav and Rathod, A. J. 2020. Enhancing Water Productivity of Rainfed Bt. Cotton (Gossypium hirsutum L.) through Various Agronomic Practices. Int.J.Curr.Microbiol.App.Sci. 9(12): 3031-3037. doi: https://doi.org/10.20546/ijcmas.2020.912.359 